Original Paper $\quad$ http://ajol.info/index.php/ijbcs $\quad$ http://indexmedicus.afro.who.int

\title{
Pre and postharvest assessment of mango anthracnose incidence and severity in the north of Côte d'Ivoire
}

\author{
Dio Dramane DEMBELE ${ }^{1,2^{*}}$, Ler-N'Og n Dadé Georges Elisée AMARI ${ }^{1}$, \\ Brahima CAMARA ${ }^{1}$, Isabelle GRECHI ${ }^{3,5}$, Jean-Yves REY ${ }^{4,5}$ and Daouda KONE ${ }^{1,2}$ \\ ${ }^{1}$ Laboratory of Plant Physiology, UFR Biosciences, University Félix HOUPHOUËT-BOIGNY, Cocody, 22 B.P \\ 582 Abidjan 22, Côte d'Tvoire. \\ ${ }^{2}$ African Center of Excellence in Climate Change, Biodiversity and Sustainable Agriculture, University of Félix \\ HOUPHOÜ̈T-BOIGNY, Cocody, 22 B.P. 582 Abidjan 22, Côte d'Ivoire. \\ ${ }^{3}$ CIRAD, UPR HortSys, F-97455 Saint-Pierre, Réunion, France. \\ ${ }^{4}$ CIRAD, UPR HortSys, F-34398 Montpellier, Réunion, France. \\ ${ }^{5}$ HortSys, Université Montpellier, CIRAD, Montpellier, France. \\ *Corresponding author; E-mail: dembeledio@yahoo.fr; Tel: (+225) 08061764.
}

\section{ACKNOWLEDGEMENTS}

The authors are grateful to the Foundation Louis Omer DECUGIS for funding this research.

\begin{abstract}
Mango is one of the most economically important fruit crop in the north of Côte d'Ivoire. However, its production and productivity are limited by various biotic and abiotic factors. Amongst fungal disease, mango anthracnose is recorded to be the most important disease in the northern districts. This study assessed the incidence and severity of pre- and post-harvest anthracnose to compare the level of orchard infestation in the seven mango producing districts in the north of Côte d'Ivoire. Anthracnose disease incidence and severity varied from locality to locality both in dry and rainy season. Disease intensity was higher in rainy season than dry season. In dry and rainy seasons, the highest disease incidence (19.08\% and $32.25 \%)$ was recorded in Bèrèdougou and the least in Zèguèrè. Pre and post-harvest anthracnose correlated significantly indicating that infection initiated in field and remained latent until fruits repining. The disease was also more severe on fruits than leaves. On fruits disease incidence and severity were higher in Dianra village (90\% and 100\%) and Bèrèdougou (36\% and $40 \%)$. The lowest disease incidence $(7.5 \%)$ and severity $(1.5 \%)$ on fruits were observed in Zèguèrè. This study showed that anthracnose disease is one the most important threat to production and marketing of fresh mango fruits in the north of Côte d'Ivoire.
\end{abstract}

(C) 2019 International Formulae Group. All rights reserved.

Keywords: Anthracnose, incidence, severity, mango, symptoms.

\section{INTRODUCTION}

Mangoes (Mangifera indica L.) are regarded as delicious fruits and are one of the most important fruit crops in tropical and subtropical regions of the world (Prusky et al.,
2009; Naqvi et al., 2014). They are member of the family Anacardiaceae and also known as the cashew nut family (Bally, 2006). 
In Côte d'Ivoire, mango was introduced especially in the coastal zones at the end of the XIX ${ }^{\text {th }}$ century, and began to have a significant distribution during the first half of the $X^{\text {th }}$ century (Rey et al., 2006). After its introduction, mango did not know a strong diffusion initially in the southern country because of unfavorable conditions due to agronomic (poor floral induction) and pathological reasons (fungi diseases particularly anthracnose) which constituted the limiting factors to its production. Export varieties, particularly Kent, are mainly grown in the north (N'depo et al., 2015) where climatic conditions are favorable for a quality production. Consequently, mango sector has known a great development in the northern regions of the country. However, these regions don't have homogeneous climatic conditions, particularly because of rainfall gradient stretched out from east to west. As in most of Western African countries, mangoes are mainly valorized in a fresh state by export or sale on the local market (Kante-traore et al., 2017). Annual production of mango fruits is estimated to 180000 tons and mango is the third export fresh fruit after banana and pineapple in the country. The country is the third supplier of the European market, with 32 400 tons exported in 2018. In the growing districts, mango contributes greatly in the income of most of households to improve their livelihood, as it represents the second export fruit after cashew nut in the north of Côte d'Ivoire. Thus, mango trade occupies a place of choice presenting so great economic importance among fruits marketed (Houngbo et al., 2018).

Ivorian mango production and marketing for export are limited by pre- and post-harvest disease caused by bacteria and fungi. Stakeholders estimated postharvest fruits rots associated with anthracnose as the main fungal disease of mango in the north of Côte d'Ivoire. This disease, caused by Colletotrichum species, was reported in the country and Guinea by Brun in 1951, where it is very widespread and was identified in 1979 in Côte d'Ivoire (N'guettia, 2015). However, this disease could probably exist for a long time. Further studies have shown that it remains the most important cause of postharvest mango losses in the country (Kouamé et al., 2010; N'Guettia et al., 2014).
According to former studies, there is a spatial heterogeneity of anthracnose incidence and severity from district to district. Studies showed that the incidence and severity of anthracnose recorded on mangoes collected in Odienné (Kabadougou district) and Ferkessédougou (Tchologo district) were higher than those collected in Korhogo (Poro district). Disease incidence was $24 \%$ and $26 \%$ respectively for Ferkessédougou and Odienné. Disease severity was $2 \%$ and $1.45 \%$ respectively for Ferkessédougou and Odienné. No disease was recorded in Korhogo (N'Guettia et al., 2014). This is also confirmed by orchards owners, retailers and exporters observations. They observed that mango quality from Kabadougou is lesser than in the other two districts (Tchologo and Poro). Heterogeneity in disease incidence and severity can be attributed to climatic factors such as rainfall prevailing in Kabadougou because high rainfall and humidity promote anthracnose disease (Iram et al., 2013). It can also be influenced by agronomics practices (N'Guettia et al., 2014). However, these studies were limited to three out of the seven mango producing districts in the north of Côte d'Ivoire. So information's on anthracnose incidence and severity in the others four districts (Béré, Bagoué, Folon and Hambol) are lacking. No study addressing the distribution and intensity of this disease both in the field and postharvest environment in the main production districts of commercial mango varieties was undertaken. Thus, assessing the distribution and prevalence of the anthracnose has paramount importance to design appropriate control measures (Akem, 2006; Chowdhury and Rahim, 2009).

Therefore, this study was undertaken to examine mango anthracnose disease incidence and severity both at the field and postharvest levels in the seven mango producing districts in the north of Côte d'Ivoire.

\section{MATERIALS AND METHODS \\ Study area}

The present study was carried out in the main mango producing districts (Bagoué, Béré, Folon, Hambol, Kabadougou, Poro and Tchologo) located in the north of Côte d'Ivoire from January to August 2018 (Figure 1). Two distinct seasons occur in these areas: the dry season lasts from October to April and 
the rainy season lasts from May to September (N'Guettia et al., 2014). These districts are characterized by an annual rainfall lower than $1500 \mathrm{~mm}$. Precipitations are concentrated over only one rainy season and the annual averages of temperatures ranged from 26 to $27.5{ }^{\circ} \mathrm{C}$ (Halle and Bruzon, 2006).

\section{Assessment of mango anthracnose disease intensity on leaves}

Assessment of disease intensity was carried out on leaves during both the dry season (January to February) and the rainy season (July to August) in 45 commercial orchards in 2018. These orchards were distributed in the seven districts as follow: Bagoué (6), Béré (5), Folon (4); Hambol (4), Kabadougou (4), Poro (17) and Tchologo (5). For disease assessment, ten trees per orchard were randomly sampled. From each tree, 4 growth units were randomly selected at each of four positions (north, south, east and west) in the tree. Disease intensity was assessed following a $0-5$ rating scale (Sundravadana et al., 2007) (Table 1). The number of leaves corresponding to each grade of the rating scale was noted on a data sheet for all the growth units.

\section{Assessment of mango anthracnose disease intensity on fruits}

Assessment of anthracnose disease intensity on fruits was carried out at fruit maturity during the mango harvest (April to May) in 24 orchards from five districts (Bagoué, Béré, Kabadougou, Tchologo and Poro) in 2018. Orchards were distributed between the different districts as follow: Bagoué (3), Béré (2), Kabadougou (2), Poro (15) and Tchologo (2). Four trees were randomly sampled per orchard. From each tree, five apparently healthy looking, greenmature fruits were selected throughout the tree canopy. Fruits were collected using sharp secateurs and collection baskets. These fruits were labeled and brought to the packing shed for further processing (Jabeen, 2016). They were washed in soapy water then rinsed three times with fresh water and air dried. Fruits were then stored at a room temperature ranging from 26 to $34.5{ }^{\circ} \mathrm{C}$ and relative humidity ranging from 58.5 to $78.5 \%$ for ripening. Disease assessment was carried out 15 days after harvest to observe the postharvest symptoms of anthracnose. Disease intensity was assessed following a five point visual rating scale proposed by Corkidi et al. (2006) (Table 1).

Determination of disease incidence and severity on mango leaves and fruits

After assessment of disease intensity, disease incidence and severity in each orchard on leaves and fruits were determined using the following formulas (Akhtar and Alam, 2002; Onyeani and Amusa, 2015) :

Disease incidence $(\mathrm{DI})=100 * \sum_{\mathrm{i}=1 \text { to } 5}$ $\left(\mathrm{n}_{\mathrm{i}}\right) / \mathrm{N}$

Disease severity $(\mathrm{DS})=100 * \sum_{\mathrm{i}=0}$ to 5 $\left(\mathrm{i} * \mathrm{n}_{\mathrm{i}}\right) /(\mathrm{N} * 5)$

Where $n_{i}$ is the total number of infected leaves (fruits) for the $\mathrm{i}^{\text {th }}$ score scale and $\mathrm{N}$ is the total number of leaves (fruits) observed in the orchard.

\section{Statistical analysis}

Data collected were analyzed using $\mathrm{R}$ software version 3.6.0 (R Core Team, 2019). Data of anthracnose incidence and severity were subjected to one way analysis of variance (ANOVA). When a significant difference was observed between the seven localities and/or the two seasons, the Turkey's Post hoc test was used to separate means of disease incidence and severity at 5\% level of significance. Pearson's correlation analysis was used to examine the relationship between disease incidence and severity on leaves and those obtained on fruits. 


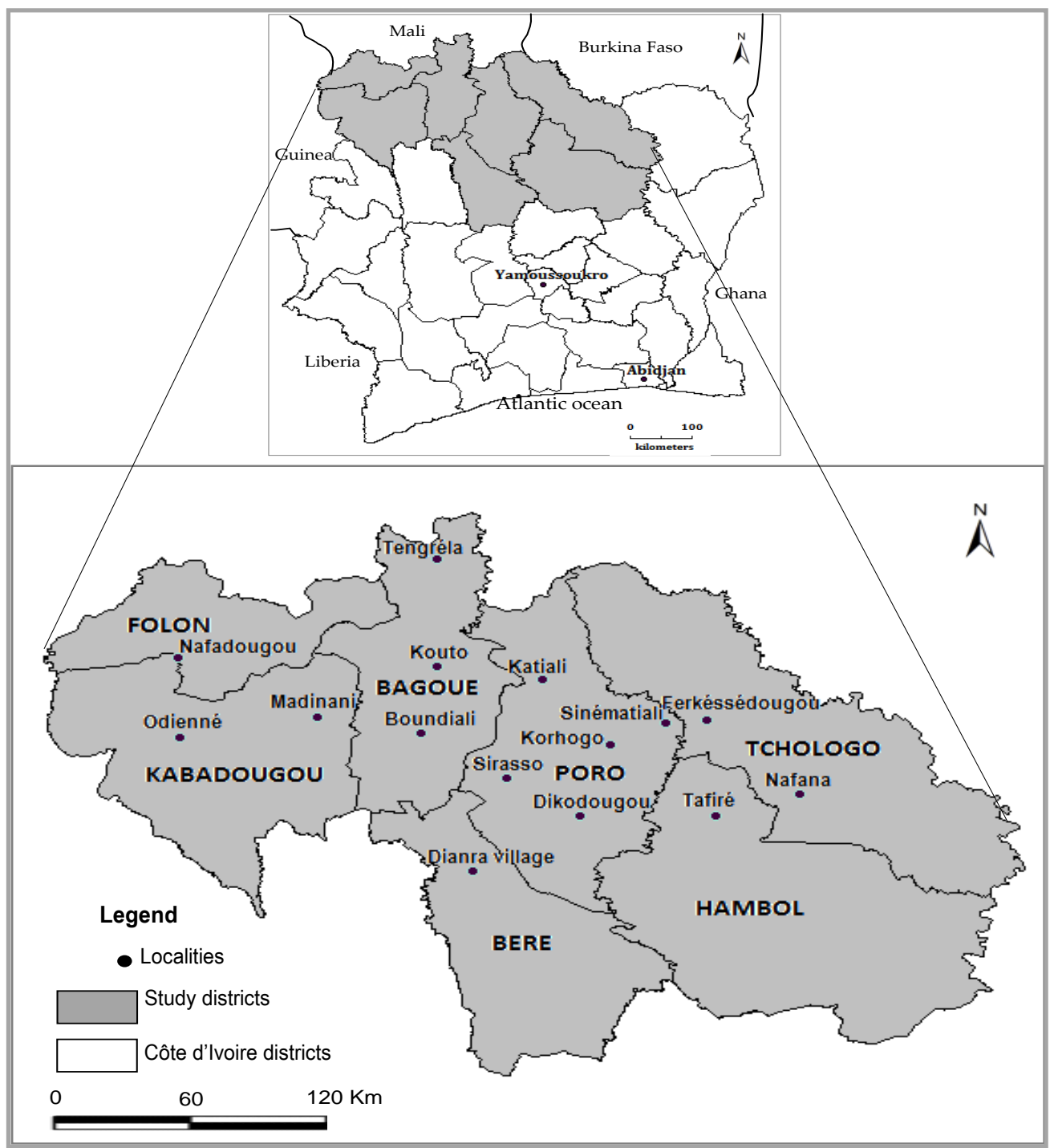

Figure 1: Map of the study districts located in the north of Côte d'Ivoire.

Table 1 : Scale for the assessment of mango anthracnose severity on leaves (Suharban et al., 1985) and fruits (Corkidi et al., 2006).

\begin{tabular}{lllll}
\hline \multirow{2}{*}{ Grade } & Leaves & \multicolumn{3}{l}{ Fruits } \\
\cline { 2 - 5 } & Disease intensity (\%) & Description & $\begin{array}{l}\text { Disease intensity } \\
(\boldsymbol{\%})\end{array}$ & Description \\
\hline 0 & 0 & No spots & $0-1$ & No disease \\
1 & $1-20$ & $1-5$ spots & $1-5$ & Slight disease \\
2 & $21-40$ & $6-10$ spots & $6-9$ & Moderate disease \\
3 & $41-60$ & $11-15$ spots & $10-49$ & Severe disease \\
4 & $61-80$ & $16-25$ spots & $50-100$ & Very severe \\
5 & $>80$ & $>25$ spots & disease \\
\hline
\end{tabular}




\section{RESULTS}

\section{Symptoms of anthracnose disease}

Anthracnose disease symptoms on leaves were observed in most of the orchards surveyed. However, symptoms were observed on fruits 15 days after incubation for disease assessment. On leaves, two types of symptoms were observed. The first type was small dark to brown spots lesions that dry up and fall out giving an appearance of perforated leaves (Figure 2A). The second type was observed when lesions coalesced to form large necrotic areas along leaf margins. Leaves were severely affected and usually curled (Figure 2B). On ripe fruits dark brown to black irregulars lesions of different sizes were observed. In some cases, these lesions coalesced to form large spots which caused fruits rotting (Figure 2C and D).

\section{Incidence and severity of anthracnose on mango leaves}

The survey conducted during the dry and rainy seasons in 2018 has shown that anthracnose disease on leaves is common in all the mango growing districts in the north of Côte d'Ivoire. Disease incidence and severity were significantly higher in rainy season than in dry season ( $\mathrm{P}<0.05$ for DI and DS). DI was $10.75 \%$ and $8.92 \%$ respectively for rainy season and dry season. DS was $2.28 \%$ and $1.91 \%$ respectively for rainy season and dry season (Figure 3).

The disease incidence and severity on leaf varied significantly between districts $(\mathrm{P}<0.001$ for DI and DS). During the two seasons mean disease incidence and severity on leaves across the different localities ranged respectively from $1.29 \%$ to $25.66 \%$ and $0.26 \%$ to $5.26 \%$ (Table 2). The highest DI was noticed in Bèrèdougou $(25.66 \%)$, Kabadougou district and Nafana (18.93\%), Tchologo district. Similarly, DS was higher in Bèrèdougou $(5.26 \%)$ and Nafana $(4.16 \%)$. However, disease incidence was lower in Zèguèrè $(1.29 \%)$ and Fapaha (1.90\%) in Poro districts. The lowest mean of disease severity across the two seasons was also noticed in Zèguèrè $(0.26 \%)$ and Fapaha $(0.36 \%)$.
Comparing the two seasons, the disease incidence ranged from $0.75 \%$ to $19.08 \%$ and $1.82 \%$ to $32.85 \%$ respectively for dry season and rainy season. DS ranged from $0.15 \%$ to 3.91 and $0.36 \%$ to $6.61 \%$ respectively for dry season and rainy season (Table 3). In dry season, the highest disease incidence $(19.08 \%)$ and severity $(3.91 \%)$ were noticed in Bèrèdougou (Kabadougou district). Similarly, the highest disease incidence $(32.25 \%)$ and severity $(6.66 \%)$ were noticed in the same locality in rainy season. The lowest DI $(0.75 \%)$ and DS $(0.15 \%)$ were noticed in Zèguèrè (Poro district) in dry season. DI (1.82\%) and DS (0.36\%) were also lower in the same locality in rainy season.

Disease incidence and severity were significantly correlated $(\mathrm{r}=0.99 ; \quad \mathrm{P}<0.001)$ between the two seasons. Similarly, it was positively correlated $(\mathrm{r}=0.99 ; \mathrm{P}<0.001)$ both in dry and rainy seasons.

\section{Incidence and severity of anthracnose on mango fruits}

Anthracnose disease was found on fruits fifteen days after incubation at temperature ranged from 26 to $34.50{ }^{\circ} \mathrm{C}$ and relative humidity ranged from 58.5 to $78.50 \%$. The disease incidence and severity on fruits varied significantly between the different localities surveyed $(\mathrm{P}<0.001$ for DI and DS). The mean disease incidence and severity ranged respectively from $7.5 \%$ to $100 \%$ and $1.5 \%$ to $40 \%$ (Table 4). The disease incidence and severity were higher in Dianra village (Béré districts) and Bèrèdougou (Kabadougou district) than in the others localities. Disease incidence was respectively $90 \%$ and $100 \%$ for Dianra village and Bèrèdougou. The disease severity was $36 \%$ and $40 \%$ respectively for these two localities. The lowest disease incidence $(7.5 \%)$ and severity $(1.5 \%)$ were observed in Zèguèrè (Poro districts). Anthracnose disease incidence $(\mathrm{P}<0.001)$ and severity $(\mathrm{P}<0.001)$ on leaves were significantly correlated to those on fruits for the 19 localities surveyed. 

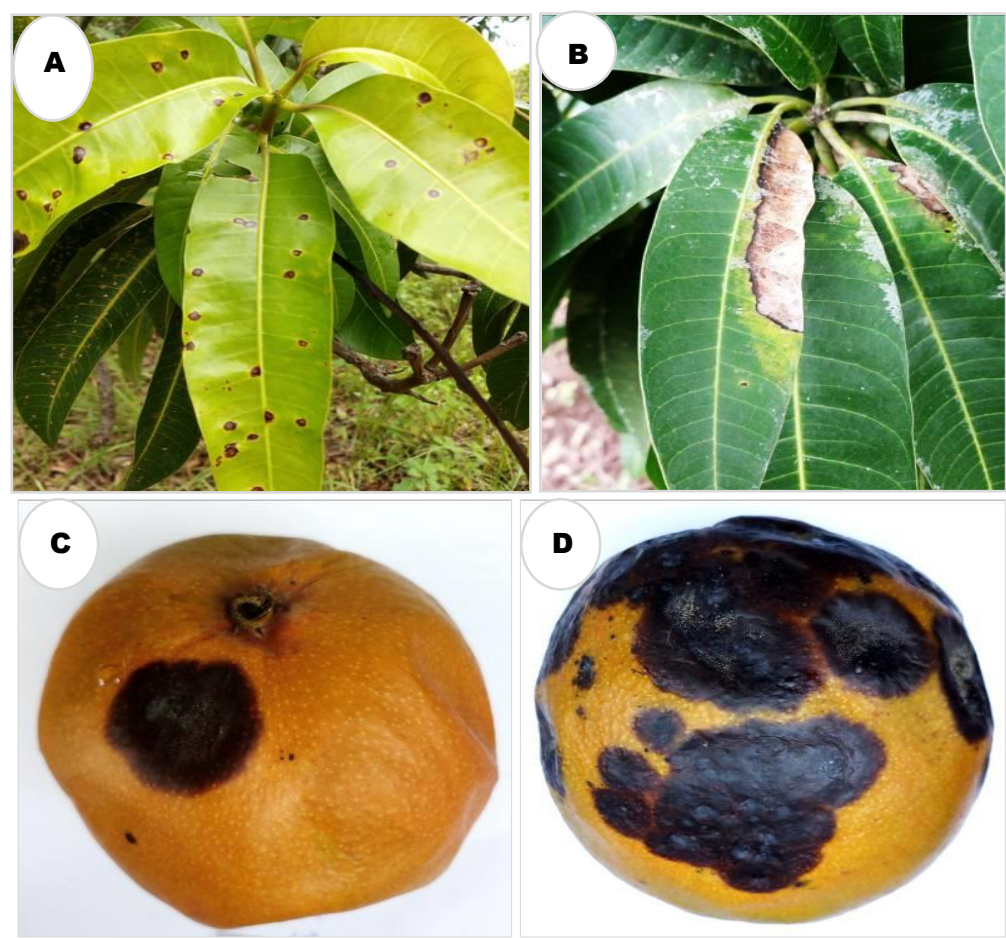

Figure 2: Anthracnose symptoms on leaves (A and B); single lesion (C) and irregular lesions coalesced to form large spots (D) on ripe fruits.

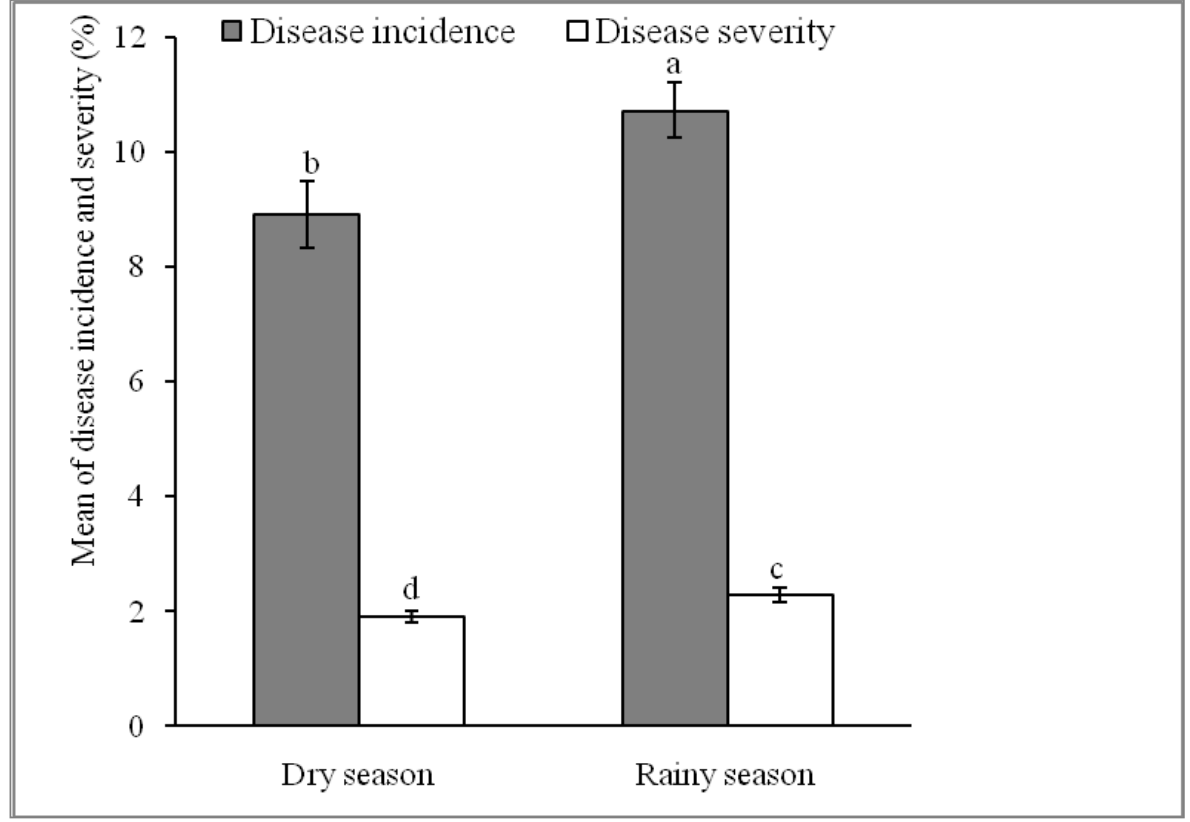

Bars of a same color with different letter(s) are significantly different according to Tukey's test at $\mathrm{P}<0.05$.

Figure 3: Disease incidence and severity $($ mean $\pm \mathrm{SD})$ of mango anthracnose on leaves in dry and rainy seasons. 
Table 2: Disease incidence and severity $(m e a n \pm S D)$ of mango anthracnose on leaves for the two seasons across the surveyed localities.

\begin{tabular}{llll}
\hline Districts & Localities & Disease incidence & Disease severity \\
\hline \multirow{2}{*}{ Bagoué } & 1- Katanra & $13.20 \pm 12.09 \mathrm{bcd}$ & $2.72 \pm 2.51 \mathrm{ijk}$ \\
& 2- Boundiali & $11.87 \pm 6.17 \mathrm{cde}$ & $2.46 \pm 1.33 \mathrm{jkl}$ \\
& 3- Tengréla & $11.73 \pm 13.63 \mathrm{cde}$ & $2.70 \pm 3.34 \mathrm{jk}$ \\
\hline Béré & 4- Dianra village & $6.94 \pm 6.51 \mathrm{efg}$ & $1.45 \pm 1.37 \mathrm{klmn}$ \\
\hline Halon & 5- Nafadougou & $16.31 \pm 10.53 \mathrm{bc}$ & $3.48 \pm 2.28 \mathrm{hij}$ \\
\hline Kabadougou & 6- Tafiré & $15.26 \pm 11.85 \mathrm{bc}$ & $3.28 \pm 2.81 \mathrm{ij}$ \\
\hline 7- Bèrèdougou & $25.66 \pm 11.32 \mathrm{a}$ & $5.26 \pm 2.38 \mathrm{~h}$ \\
& 8- Madinani & $12.55 \pm 10.07 \mathrm{~cd}$ & $2.67 \pm 2.21 \mathrm{jk}$ \\
\hline Poro & 9- Dikodougou & $8.82 \pm 7.06 \mathrm{def}$ & $1.88 \pm 1.54 \mathrm{klm}$ \\
& 10- Kombolokoura & $5.72 \pm 6.40 \mathrm{efg}$ & $1.19 \pm 1.40 \mathrm{klmn}$ \\
& 11- Sirasso & $5.53 \pm 6.23 \mathrm{efg}$ & $1.12 \pm 1.26 \mathrm{lmn}$ \\
& 12- Kohokaha & $4.27 \pm 3.90 \mathrm{efg}$ & $0.89 \pm 0.81 \mathrm{lmn}$ \\
& 13- Sinématiali & $2.73 \pm 3.20 \mathrm{fg}$ & $0.58 \pm 0.69 \mathrm{lmn}$ \\
& 14- Kouolo & $2.36 \pm 2.50 \mathrm{fg}$ & $0.51 \pm 0.60 \mathrm{lmn}$ \\
& 15- Tioro & $2.08 \pm 3.18 \mathrm{fg}$ & $0.45 \pm 0.75 \mathrm{lmn}$ \\
& 16- Fapaha & $1.90 \pm 3.52 \mathrm{fg}$ & $0.38 \pm 0.70 \mathrm{mn}$ \\
& 17- Zeguèrè & $1.29 \pm 2.20 \mathrm{~g}$ & $0.26 \pm 0.44 \mathrm{n}$ \\
\hline Tchologo & 18- Nafana & $18.93 \pm 13.54 \mathrm{ab}$ & $4.16 \pm 3.18 \mathrm{hi}$ \\
& 19-Ferkéssédougou & $7.13 \pm 5.95 \mathrm{defg}$ & $1.49 \pm 1.25 \mathrm{klmn}$ \\
\hline
\end{tabular}

Percentage of incidence and severity with the same letter are not significantly different according to Tukey's test at $\mathrm{P}<0.05 \%$.

Table 3: Disease incidence and severity (mean $\pm \mathrm{SD}$ ) of mango anthracnose on leaves in the two seasons across the surveyed localities.

\begin{tabular}{llllll}
\hline Districts & Localities & $\begin{array}{l}\text { Dry season } \\
\text { Incidence }\end{array}$ & Severity & $\begin{array}{l}\text { Rainy season } \\
\text { Incidence }\end{array}$ & Severity \\
\hline Bagoué & 1- Katanra & $10.83 \pm 11.11 \mathrm{abc}$ & $2.25 \pm 2.33 \mathrm{def}$ & $15.57 \pm 12.87 \mathrm{hij}$ & $3.19 \pm 2.65 \mathrm{mnop}$ \\
& 2- Boundiali & $12.21 \pm 7.18 \mathrm{abc}$ & $2.51 \pm 1.54 \mathrm{def}$ & $11.53 \pm 5.39 \mathrm{hijk}$ & $2.41 \pm 1.17 \mathrm{nopqr}$ \\
& 3-Tengréla & $12.49 \pm 14.76 \mathrm{ab}$ & $2.92 \pm 3.64 \mathrm{de}$ & $10.95 \pm 12.64 \mathrm{ijk}$ & $2.48 \pm 3.07 \mathrm{nopq}$ \\
\hline Béré & 4-Dianra village & $4.98 \pm 5.31 \mathrm{c}$ & $1.05 \pm 1.13 \mathrm{f}$ & $9.08 \pm 7.05 \mathrm{jk}$ & $1.89 \pm 1.48 \mathrm{opqr}$ \\
\hline Folon & 5- Nafadougou & $15.78 \pm 9.99 \mathrm{a}$ & $3.39 \pm 2.21 \mathrm{~d}$ & $16.84 \pm 11.15 \mathrm{hi}$ & $3.57 \pm 2.36 \mathrm{mn}$ \\
\hline Hambol & 6- Tafiré & $13.36 \pm 11.95 \mathrm{ab}$ & $2.89 \pm 2.93 \mathrm{de}$ & $17.80 \pm 11.44 \mathrm{hi}$ & $3.79 \pm 2.61 \mathrm{mn}$ \\
\hline Kabadougou & 7- Bèrèdougou & $19.08 \pm 6.94 \mathrm{a}$ & $3.91 \pm 1.56 \mathrm{~d}$ & $32.25 \pm 11.27 \mathrm{~g}$ & $6.61 \pm 2.34 \mathrm{l}$ \\
& 8- Madinani & $10.07 \pm 7.58 \mathrm{abc}$ & $2.14 \pm 1.69 \mathrm{def}$ & $15.04 \pm 11.68 \mathrm{hij}$ & $3.21 \pm 2.54 \mathrm{mno}$ \\
\hline
\end{tabular}




\begin{tabular}{llllll} 
Poro & 9-Dikodougou & $8.46 \pm 6.83 \mathrm{abc}$ & $1.81 \pm 1.46 \mathrm{def}$ & $9.35 \pm 7.57 \mathrm{ijk}$ & $1.99 \pm 1.68 \mathrm{nopqr}$ \\
& 10- Kombolokoura & $5.66 \pm 6.16 \mathrm{bc}$ & $1.13 \pm 1.23 \mathrm{ef}$ & $5.77 \pm 6.82 \mathrm{jk}$ & $1.25 \pm 1.59 \mathrm{opqr}$ \\
11- Sirasso & $5.90 \pm 6.31 \mathrm{bc}$ & $1.20 \pm 1.29 \mathrm{ef}$ & $5.11 \pm 6.22 \mathrm{k}$ & $1.02 \pm 1.24 \mathrm{pqr}$ \\
12- Kohokaha & $4.57 \pm 3.62 \mathrm{c}$ & $0.99 \pm 0.77 \mathrm{f}$ & $3.95 \pm 4.35 \mathrm{k}$ & $0.79 \pm 0.87 \mathrm{pqr}$ \\
13- Sinématiali & $3.80 \pm 4.02 \mathrm{c}$ & $0.79 \pm 0.88 \mathrm{f}$ & $1.67 \pm 1.59 \mathrm{k}$ & $0.37 \pm 0.35 \mathrm{qr}$ \\
14- Kouolo & $1.82 \pm 2.03 \mathrm{c}$ & $0.36 \pm 0.41 \mathrm{f}$ & $2.89 \pm 2.91 \mathrm{k}$ & $0.65 \pm 0.75 \mathrm{pqr}$ \\
15- Tioro & $2.55 \pm 4.05 \mathrm{c}$ & $0.57 \pm 0.98 \mathrm{f}$ & $1.60 \pm 2.13 \mathrm{k}$ & $0.32 \pm 0.43 \mathrm{qr}$ \\
16- Fapaha & $2.68 \pm 4.75 \mathrm{c}$ & $0.54 \pm 0.95 \mathrm{f}$ & $1.12 \pm 1.27 \mathrm{k}$ & $0.23 \pm 0.26 \mathrm{r}$ \\
& 17- Zeguèrè & $0.75 \pm 1.6 \mathrm{c}$ & $0.15 \pm 0.32 \mathrm{f}$ & $1.82 \pm 2.61 \mathrm{k}$ & $0.36 \pm 0.52 \mathrm{qr}$ \\
\hline Tchologo & 18- Nafana & $16.45 \pm 13.41 \mathrm{a}$ & $3.62 \pm 3.13 \mathrm{~d}$ & $21.41 \pm 13.47 \mathrm{gh}$ & $4.70 \pm 3.20 \mathrm{~lm}$ \\
& 19-Ferkéssédougou & $7.17 \pm 6.25 \mathrm{abc}$ & $1.47 \pm 1.31 \mathrm{def}$ & $7.09 \pm 5.81 \mathrm{jk}$ & $1.50 \pm 1.23 \mathrm{opqr}$ \\
\hline
\end{tabular}

Percentage of incidence and severity with the same letter are not significantly different according to Tukey's test at $\mathrm{P}<0.05 \%$.

Table 4: Disease incidence and severity (mean $\pm \mathrm{SD}$ ) of mango anthracnose on fruits across the surveyed localities.

\begin{tabular}{llll}
\hline Districts & Localities & Disease incidence & Disease severity \\
\hline \multirow{2}{*}{ Bagoué } & 1- Katanra & $10.0 \pm 30.78 \mathrm{~g}$ & $5.0 \pm 18.21 \mathrm{jkl}$ \\
& 2- Boundiali & $25.0 \pm 44.43 \mathrm{defg}$ & $5.0 \pm 8.88 \mathrm{jkl}$ \\
& 3- Tengréla & $70.0 \pm 47.02 \mathrm{abc}$ & $30.0 \pm 26.35 \mathrm{hi}$ \\
\hline Béré & 4- Dianra village & $90.0 \pm 30.38 \mathrm{ab}$ & $36.0 \pm 27.62 \mathrm{~h}$ \\
\hline \multirow{2}{*}{ Kabadougou } & 5- Bèrèdougou & $100.0 \pm 0.00 \mathrm{a}$ & $40.0 \pm 25.13 \mathrm{~h}$ \\
& 6- Madinani & $70.0 \pm 47.02 \mathrm{abc}$ & $22.0 \pm 24.19 \mathrm{hijk}$ \\
\hline \multirow{2}{*}{ Poro } & 7- Dikodougou & $60.0 \pm 49.61 \mathrm{bcd}$ & $25.5 \pm 30.04 \mathrm{hij}$ \\
& 8- Kombolokoura & $42.5 \pm 50.06 \mathrm{cdef}$ & $15.5 \pm 23.74 \mathrm{ijkl}$ \\
& 9- Sirasso & $90.0 \pm 30.78 \mathrm{ab}$ & $26.0 \pm 19.57 \mathrm{hij}$ \\
& 10- Kohokaha & $10.0 \pm 30.78 \mathrm{~g}$ & $2,0 \pm 6.16 \mathrm{kl}$ \\
& 11- Sinématiali & $22.5 \pm 42.29 \mathrm{fg}$ & $7.5 \pm 17.35 \mathrm{jkl}$ \\
& 12- Kouolo & $60.0 \pm 50.26 \mathrm{bcde}$ & $12.0 \pm 10.05 \mathrm{ijkl}$ \\
& 13- Tioro & $25.0 \pm 44.43 \mathrm{efg}$ & $5.0 \pm 8.88 \mathrm{jkl}$ \\
& 14- Fapaha & $10.0 \pm 30.38 \mathrm{~g}$ & $3.5 \pm 13.5 \mathrm{kl}$ \\
\hline Pchologo & 15- Zeguèrè & $7.5 \pm 26.67 \mathrm{~g}$ & $1.5 \pm 5.331$ \\
\hline Percentage of incidence and severity with the same letter are not significantly different according to Tukey’s test at P<0.05\%.
\end{tabular}




\section{DISCUSSION}

This study aimed at assessing the preand postharvest incidence and severity of anthracnose disease infecting mango leaves and fruits in the main producing districts located in the north of Côte d'Ivoire.

The results indicated that during the field survey, anthracnose symptoms were observed in all of the orchards surveyed. On leaves, two types of symptoms were observed, small dark to brown spots that were often coalesced to form irregular lesions. The second type was observed when lesions coalesced to form large necrotic areas along the margin of leaves. On ripening fruits, dark brown to black irregulars lesions of different sizes were observed. In some cases, these lesions coalesced to form large spots which caused fruits rotting. These descriptions were similar to the observation of Onyeani et al. (2012) and Pandey et al. (2012) on mango leaves and fruits infected by anthracnose disease.

Field assessment of anthracnose showed variations in disease incidence and severity observed among the different localities surveyed. The highest disease incidence and severity on leaves occurred in Bèrèdougou (Kabadougou district) and Nafana (south of Tchologo district) whereas disease was lesser in Zèguèrè (Poro district) both in rainy and dry seasons. This study could be in agreement with the report of N'Guettia et al. (2014) that showed anthracnose disease incidence and severity close to zero in Korhogo in Poro district and the highest were observed in Odienné in Kabadougou district. The highest disease intensity in Kabadougou and Tchologo could be attributed to environmental factors such as rainfall. In Kabadougou district annual rainfall is closed to $1400 \mathrm{~mm}$ (Goula et al., 2010) and is higher than in the others mango production districts in the north of Côte d'Ivoire. In the south of Tchologo district, rainfall is also higher than in the others part of this district. Rainfall has a major impact on the distribution and spread of mango anthracnose by serving as a major vehicle for the dispersal of conidia within the tree canopy and also providing free moisture for the germination of conidia (Arauz, 2000; Akem, 2006). Studies have already indicated that anthracnose cause significant impact in areas where rainfall is prevalent (Arauz, 2000; Onyeani et al., 2012; Chala et al., 2014). The highest disease intensity in Bèrèdougou and Nafana could be also attributed to poor management practices. Farmers did not make sanitation, prune or remove debris of diseased stems and fruits in their orchards. Those could be the first source of C. gloeosporioides inoculums which could rapidly initiate an epidemic once favorable condition for dispersal and infection occurred (Arauz, 2000; Estrada et al., 2000; Tucho et al., 2014). isease intensity was lesser in Poro district, in addition to less favorable environmental factors, could be attributed to sanitation. Most of orchards in this district were relatively cleaner than the others in Kabadougou. Also, most of mango packing sheds for exportation are located in Poro and Tchologo districts. Thus, farmers are making efforts to better manage their orchards in order to benefit from better selling prices.

Disease incidence and severity on fruits varied significantly across the surveyed localities. Both disease incidence and severity were higher on fruits than on leaves. The disease mainly developed during ripening. This could be attributed to fruit softening during the ripening process which causes break down of the natural defense mechanisms and enhances latent infections of anthracnose (Tucho et al., 2014). This could also be attributed to postharvest decay due to the rapid development of disease during storage and ripening (Prusky et al., 2009). The disease incidence and severity were higher in Béré and Kabadougou than in the others districts. The lowest incidence and severity were observed in Poro districts. Disease incidence and severity recorded on leaves in farmer's fields and also on fruits after ripening were higher in Kabadougou. This suggest the presence of a strong relationship between pre- and postharvest 
anthracnose infection (Tucho et al., 2014). However, disease incidence and severity recorded in Dianra village were lower on leaves but higher on fruits. The highest disease incidence and severity recorded on fruits could be owed to latent infections which occurred before harvest and then remain quiescent until some point during ripening (Akem, 2006). Thus, in field sources of inoculum are thought to be leaves, buds and mummified fruits (Fotsa et al., 2014).

As for leaves, environmental factors and management practices could explain the variability of disease incidence and severity between the districts. The combination of pruning, weeding and spading has been reported increasing healthy fruit per plant and yield per hectare as well as reducing anthracnose occurrence on mango for two consecutive years (Chowdhury et al., 2008). Pruning also helps to lower down the incidence of anthracnose disease by reduction of disease inoculums load, possible due to enough penetration of sunlight, which reduced the preharvest growth of the organisms down the inflorescence and peduncle across the canopy (Rehman et al., 2015).

Results also indicated a strong significantly relationship between disease incidence and severity recorded on leaves both in dry and rainy seasons. This relationship was also significant for fruits. This might be interpreted that the only assessment of anthracnose incidence could be used to estimate its severity levels as indicated by Cardoso et al. (2004) for the analysis of the relationship between incidence and severity of cashew gummosis in semiarid north-eastern Brazil. Copes and Stevenson (2008) also noted that estimates of incidence are generally more precise than estimates of severity, and could provide an alternative assessment approach that may be transformed into a severity measurement when a mathematical relationship exists between the two parameters.

\section{Conclusion}

This study has shown that anthracnose of mango is present in all of the farms surveyed in the seven districts. However, the incidence and severity of this disease varied significantly among the different localities. The highest disease incidence and severity on leaves were recorded in Kabadougou districts whereas disease was lesser in Poro district both in rainy and dry seasons. Disease intensity was also higher on leaves in rainy season than dry season. The disease incidence and severity on fruits varied across the surveyed localities. A strong significant relationship between disease incidence and severity was recorded on leaves both in dry and rainy seasons. This relationship was also significant for fruits. Anthracnose disease incidence and severity recorded on leaves were significantly correlated to those on fruits. Therefore, anthracnose infections on fruits initiated on field remain quiescent and due to the break down of the natural defense mechanisms infections occurred at postharvest. This study confirmed observations of mango retailers and exporters on the lowest quality of mango from Kabadougou district than the others districts surveyed. This suggests that an integrated management practices must be set in these two districts to improve fruits quality. But, this needs to be extended to the others districts to overcome the anthracnose by using disease control measures. Further, it could thus be recommended to investigate the etiology of mango anthracnose to identify it causal agent.

\section{COMPETING INTERESTS}

The authors declare that they have no competing interests.

\section{AUTHORS' CONTRIBUTIONS}

DDD has conducted field survey, data collection and prepared the original draft; LDGEA and BC have conceptualized and supervised data collection; IG, JYR and DK have approved the sampling methodology, 
validated the data analysis and reviewed the manuscript.

\section{ACKNOWLEDGMENTS}

We would like to thank the Societe de Diverses Prestations et d'Exportations (Sodipex SARL) for their technical support.

\section{REFERENCES}

Akem CN. 2006. Mango anthracnose disease: present status and future research priorities. Plant Pathol. J., 5(3): 266273. DOI : 10.3923/ppj.2006.266.273.

Akhtar KP, Alam SS. 2002. Assessment keys for some important diseases of mango. Pakistan J. Biol. Sci., 5(2): 246-250. DOI : $10.3923 /$ pjbs.2002.246.250.

Arauz LF. 2000. Mango anthracnose: Economic impact and current options for integrated management. Plant Dis., 84(6): 600-611. DOI: 10.1094/PDIS.2000.84.6.600.

Bally ISE. 2006. Mangifera indica (mango). In Species Profiles for Pacific Island Agroforestry. Elevitch CR (ed). Permanent Agriculture Resources (PAR): Olualoa Hawai' 1 ; 1-25.

Cardoso JE, Santos AA, Rossetti AG, Vidal JC. 2004. Relationship between incidence and severity of cashew gummosis in semiarid north-eastern Brazil. Plant Pathol., 53(3): 363-367. DOI: $10.1111 / \mathrm{j} .0032-$ 0862.2004.01007.x.

Chala A, Getahun M, Alemayehu S, Tadesse M. 2014. Survey of Mango Anthracnose in Southern Ethiopia and In-Vitro Screening of Some Essential Oils against Colletotrichum gloeosporioides. Int. J. Fruit Sci., 14(2): 157-173. DOI : 10.1080/15538362.2013.817899.

Chowdhury MNA, Rahim MA. 2009. Integrated crop management to control anthracnose (Colletotrichum gloeosporioides) of mango. J. Agric.
Rural Dev., 7: 115-120. DOI: 10.3329/jard.v7i1.4430.

Chowdhury MNA, Rahim MA, Khalequzzaman KM, Alam MJ, Humauan MR. 2008. Effect of horticultural practices on incidence of anthracnose on yield and quality of mango. Int. J. Sustain. Crop Prod., 31(2): 1-9.

Copes WE, Stevenson KL. 2008. A pictorial disease severity key and the relationship between severity and incidence for black root rot of pansy caused by Thielaviopsis basicola. Plant Dis., 92 (10): 1394-1399. DOI: 10.1094/PDIS-92-10-1394.

Corkidi G, Balderas-Ruíz KA, Taboada B, Serrano-Carreón L, Galindo E. 2006. Assessing mango anthracnose using a new three-dimensional image-analysis technique to quantify lesions on fruit. Plant Pathol., 55(2): 250-257. DOI: 10.1111/j.1365-3059.2005.01321.x.

Estrada AB, Dodd JC, Jeffries P. 2000. Effect of humidity and temperature on conidial germination and appressorium development of two Philippine isolates of the mango anthracnose pathogen Colletotrichum gloeosporioides. Plant Pathol., 49(5): 608-618. DOI: 10.1046/j.1365-3059.2000.00492.x.

Fotsa D, Houpa E, Békollé D, Thron C, Ndoumbé M. 2014. Mathematical modelling and optimal control of anthracnose. Biomath, 3: 1-16. DOI: 10.11145/j.biomath.2014.04.161.

Goula BTA, Srohourou B, Brida AB, Kanga BI, Zué KAN, Goroza G. 2010. Zoning of rainfall in Côte d'Ivoire. Int. J. Eng. Sci. Technol., 2(11): 6004-6015.

Halle B, Bruzon V. 2006. Profil environnemental de la Côte d'Ivoire. Rapport Final. Consortium AGRIFOR Consult. Côte d'Ivoire.

Houngbo HY, Chessy A, Basso PR, Anato Afora F, Sinzogan A, Saidou A, 
Vayssieres J-F, Azokpota P. 2018. Effet de la densité des fourmis rouges [Oecophylla longinoda latreille (Hymenoptera: formicidae)] des manguiers sur la teneur en sucres et acides organiques de la mangue [Mangifera indica L . (Sapindales: Anacardiaceae)]. Int. J. Biol. Chem. Sci., 12(6): 2885-2900. DOI : 10.4314/ijbcs.v12i6.32.

Iram S, Meer H, Ahmad I. 2013. Major Post Harvest Diseases of Mango and their Management. Int. J. Agron. Plant Prod., 4 (12): 3470-3484.

Jabeen A. 2016. Field and Postharvest Biology of Dendritic Spot and Stem End Rot of Mango. PhD thesis, University of Queensland, Australia, p. 158.

Kante-Traore H, Sawadogo-lingani H, Seogo I, Kabore D, Dicko MH. 2017. Procédés de transformation de la mangue et niveau de connaissance des normes de qualité par les unités de production au Burkina Faso Mango processing methods and level of knowledge of quality standards by actors in mango enterprise in Burkina Faso. Int. J. Biol. Chem. Sci., 11 (1): 195-207. DOI: 10.4314/ijbcs.v11i1.16.

Kouamé GK, Sorho F, Koné D, Bomisso LE, Aké S, Yatty J. 2011. Activité pathologique comparée de deux isolats de Colletotrichum gloeosporioïdes (PENZ.) sur deux varietés de mangues (Mangifera indica L .). Agron. Africaine, 23(1): 33-41.

Kouamé KG, Abo K, Dick E, Bomisso EL, Kone D, Aké S. 2010. Artificial wounds implication for the development of mango (Mangifera indica L. anacardiaceae) fruit disease caused by Colletotrichum gloeosporioïdes (Penz.) Sacc. (Glomerellaceae). Int. J. Biol. Chem. Sci., 4(5): 1621-1628. DOI: 10.4314/ijbcs.v4i5.65579.
N'depo O, Hala N, N'da Adopo A, Coulibaly F, Kouassi P, Vayssieres J, De Meyer M. 2015. Effective chemical control of fruit flies (Diptera: Tephritidae) pests in mango orchards in northern Côte d'Ivoire. Int. J. Biol. Chem. Sci., 9 (3): 1299-1307. DOI: 10.4314/ijbcs.v9i3.15.

N'Guettia MYN. 2015. Anthracnose de la mangue (Mangifera indica L.) en Côte d'Ivoire: Caractérisation de l'agent pathogène et efficacité in vitro et in vivo de deux fongicides chimiques. Thèse de doctorat, Université Nanagui Abrogoua, Abidjan, p. 171.

N'Guettia MYN, Kouassi N, Diallo HA, Kouakou FRYY. 2014. Evaluation of Anthracnose Disease of Mango (Mangifera indica L.) Fruits and Characterization of Causal Agent in Côte d' Ivoire. Int. J. Agric. Innov. Res., 2(6): 1008-1017.

N'Guettia MYN, Diallo AH, Kouassi N, Coulibaly F. 2013. Diversité morphologique et pathogénique des souches de Colletotrichum sp. responsables de l' anthracnose de la mangue en Côte d' Ivoire. J. Anim. Plant Sci., 18(3): 2775-2784.

Naqvi SAH, Rashida P, Malik MT, Owais M, Ummad-ud-Din U, Wazeer MS, Rehman Ateequr, Majid T, Abbas Z. 2014. Characterization of symptoms severity on various mango cultivars to quick decline of mango in district Multan. Int. J. Biosci., 4(11): 157-163. DOI: 10.12692/ijb/4.11.157-163.

Onyeani CA, Amusa NA, 2015. Incidence and severity of anthracnose in mango fruits and its control with plant extracts in south west Nigeria. Int. J. Agric. Res., 10(1): 33-43, DOI: 10.3923/ijar.2015.33.43.

Onyeani CA, Osunlaja SO, Owuru OO, Sosanya OS. 2012. Mango fruit anthracnose and the effects on mango 
yield and market values in Southwestern Nigeria. Asian J. Agric. Res., 6(4): 171179. DOI: 10.3923/ajar.2012.171.179.

Pandey A, Yadava LP, Mishra RK, Pandey BK, Muthukumar M, Chauhan UK. 2012. Studies on the incident and pathogenesis of Colletotrichum gloeosporioides penz. causes anthracnose of mango. Int. J. Sci. Nat., 3(2): 220-232.

Prusky D, Kobiler I, Miyara I, Alkan N. 2009. Fruit diseases. In The Mango: Botany, Production and Uses, Litz R.E (Ed). CABI: Wallingford, UK, 210-231.

R Core Team. 2019. R: A Language and Environment for Statistical Computing. R Foundation for Statistical Computing, Vienna, Austria.

Rehman A, Ullah Malik A, Ali H, Alam MW, Sarfraz B, Rehman A, Malik AU, Ali H, Alam MW. 2015. Preharvest factors influencing the postharvest disease development and fruit quality of mango. J. Environ. Agric. Sci., 3: 42-47.

Rey JY, Diallo TM, Vannière H, Didier C, Kéita S, Sangaré M. 2006. The mango in French-speaking West Africa. Fruits, 61(4): 281-289. DOI: 10.1051/fruits:2006027.

Sundravadana S, Alice D, Kuttalam S, Samiyappan R. 2007. Efficacy of azoxystrobin on Colletotrichum gloeosporiodes Penz growth and on controlling Mango anthracnose. Journal of Agricultural and Biological Science, 2(3): 10-15.

Tucho A, Lemessa F, Bérécha G. 2014. Distribution and Occurrence of Mango Anthracnose (Colletotrichum gloesporioides). Plant Pathol. J., 13(4): 268-277.

DOI: 